\title{
Evaluation of Suitable Sowing Dates and Varieties for the Management of Linseed (Linum usitatissimum L.) wilt Under Wilt-Sick Field Conditionincited by Fusarium oxysporum f.sp. lini. (Bolley) Synder and Hansen
}

\author{
Somesh $^{1}$, Narendra Singh ${ }^{1}$ and Sumit Kumar ${ }^{2 *}$ \\ ${ }^{1}$ Department of Plant Pathology, C.S.A. University of Agriculture and Technology, Kanpur \\ 208002, UP, India \\ ${ }^{2}$ Department of Mycology and Plant Pathology, Institute of Agricultural Sciences, Banaras \\ Hindu University, Varanasi 221005, UP, India \\ *Corresponding author
}

\begin{abstract}
A B S T R A C T
Field experiments conducted during 2016-2017 for the management of wilt of linseed (Linum usitatissimum L.), eleven varieties namely, Jeevan, Sweta, Parvati, Surbhi, NDL-2004-05, Kiran, RLC-92, Indira Alsi, Dipika, Shekhar including susceptible cultivar Chambal were sown in the month of October, 2016. Out of 11 varieties, the maximum initial plant population (537.67 and 516.33/ plot) was noted with Shekhar followed by NDL-2004-05 respectively. Susceptible check Chambal has average initial plant population of $490.67 /$ plot after germination. The minimum percentage of wilting was recorded in cultivar RLC-92 (5.47 per cent) followed by Jeevan (07.61 per cent) and Indira Alsi (07.85 Per cent), respectively but all were at par statistically. Maximum per cent of wilting was recorded in susceptible cultivar Chambal (70.87 Per cent) followed by Sweta (61.64 Per cent) and Shekhar (61.50 per cent). Maximum seed yield of $996.29 \mathrm{~kg} / \mathrm{ha}$ was recorded in cultivar RLC-92 followed by Dipika (914.07kg/ha) and NDL-2004-5 (909.62 kg/ha), respectively, which was significantly higher over others. Linseed cultivar Chambal was sown in 7 different dates starting from 10 October, 2017 to 9 December, 2017 of 10 days intervals. Maximum wilting of plants (66.66 Per cent) were noted in $1^{\text {st }}$ date $(10-10-2017)$ of sowing which decreased with delayed sowing and minimum (14.31 Per cent) was recorded in December sown (09-12-2017) crop. Significant difference in wilting percentage was noted in crops sown on different dates. Maximum yield of $582.95 \mathrm{~kg} / \mathrm{ha}$ was noted in crop sown on 19-11-2017 followed by crop sown on 09-11-2017 (434.81kg/ha) and 30-10-2017 (414.81kg/ha), respectively.
\end{abstract}

\section{Introduction}

Linseed (Linum usitatissimum L.) is an important ancient crop and also known as "Ulsee" or "Tisee", which is grown mainly for commercial oil and seeds containing 33 to $47 \%$ of oil content. Asia and Mediterranean coast are the oldest regions of linseed. In world, linseed cultivated mostly temperate, subtropical and tropical regions. Taxonomically, linseed $(2 \mathrm{n}=30)$, belongs to order Linales and the family Linaceae. Globally linseed production is 21.23 lac tonnes from $21.12 \mathrm{lac} / \mathrm{ha}$ with an average yield of $1006 \mathrm{~kg} / \mathrm{ha}$. While our national production is 1.54 lac tonnes from an area of 
3.42 lac ha with poor productivity of 449 $\mathrm{kg} / \mathrm{ha}$. India second ranks in area after Canada in the world, but in production fourth place after Canada, China and U.S.A. Linseed oil is rich in fat and in addition they contain a high level of protein, it contributes edible oil (fats) and Vanaspati ghee to human diet. Edible oils are concentrated source of energy. The energy content of oil is much higher $(39.80 \mathrm{MJ} / \mathrm{kg}$ ) than crude protein $(23.88 \mathrm{MJ} / \mathrm{kg})$ or carbohydrate $(16.76 \mathrm{MJ} / \mathrm{kg})$. They contain useful carbohydrates, vitamins and provide essential fatty acids. Edible oil cakes are fed to cattle, while non-edible cakes are used as organic manures; it contains about $5 \%$ nitrogen, $1.4 \%$ phosphorus and $1.8 \%$ potash. Thus, linseed is a multipurpose crop and every effort should be taken to boost up the production of this valuable crop. The production of this important oil and fibre yielding crop is very low in India. Amongst the various factors responsible for lowering down its yield, the diseases especially those caused by fungi are considered to be major one. The important biotic stresses affecting this crop are wilt, powdery mildew, rust and Alternaria blight (Kolte and Fitt, 1997). Among biotic stresses linseed wilt incited by Fusarium oxysporum f. sp. lini is the most destructive disease. Linseed wilt was first reported in Madhya Pradesh at 1923. Since then, it has been found in other linseed growing areas of the country (Rae, 1926). Sattar and Hafiz (1952) reported losses by wilt disease in linseed crop up to $80 \%$ under favourable conditions and appeared epidemic in 1952 at the Govt. research form Kanpur. Therefore, management of the disease is very difficult and single method is not sufficient for management of the disease. Considering the above point's in view the importance of the crop and seriousness of the disease the present investigation was under taken with evaluation of suitable sowing date and varieties for the management of linseed wilt under wilt-sick field condition.

\section{Materials and Methods}

\section{Collection of infected plant samples}

Collect the naturally affected by linseed wilt plants from Crop Research Farm, C. S. Azad University of Agriculture and Technology, Kanpur, during Rabi season, 2016-2017. Infected plants apparently showing typical wilt symptoms were collected and brought to the laboratory for initial examination. Diseased samples were pressed in between the fold of sterilized blotting paper and preserved at $4-6^{\circ} \mathrm{C}$ in refrigerator for further study. All the collected samples were examined in the laboratory for the presence of causal organism and virulence study.

\section{Isolations of pathogen}

The causal organisms were isolated from roots that affected by wilt. First affected roots washed with tap water to remove dust particles and then thoroughly washed with sterilized distilled water in order to remove the other surface contaminants. A small piece of diseased portion along with healthy parts was cut and dipped in0.1 per cent mercuric chloride solution for 30 seconds and washed thoroughly three to four times with sterilized distilled water to allow remove the particles of mercuric chloride. The excess moisture was removed by placing them in the fold of sterilized blotting papers. These pieces were transferred on Potato Dextrose Agar (PDA) medium in Petri dishes. The plates incubated at $28 \pm 2^{\circ} \mathrm{C}$ temperature for 7 days in B.O.D. incubator. The Petri plates were observed daily to find out the presence of mycelium and soon, the mycelial growth was visible around these pieces.

\section{Purification of pathogen}

The purification of fungal isolates was taken following single spore isolation technique 
(Choi, 1999). A dilute spore suspension was poured on plain agar Petri dishes to form a very thin layer on it and spores allowed settling down on the agar surface. Settled spores were separated out from each other, selected under the microscope and encircled with the help of dummy cutter in Petri dishes. They were lifted along with agar blocks and transferred to Petri dishes containing sterilized 2 per cent PDA medium. After proper growth of fungus obtained by single spore culture regular sub-culturing was done to check contamination, till pure cultures were obtained. The culture was then transferred into the incubator at 6 to $8^{\circ} \mathrm{C}$ for further use.

\section{Identifications of Fusarium oxysporum f.sp. lini}

The isolated pathogen was identified on the basis of its morphological and cultural characters and pathogenic behaviour towards the host.The presence of white fluffy colony of Fusarium oxysporum f.sp. lini was identified based on their morphological characters with the help of microscope. The mycelium was septate, branched and intracellular, developing into thin stroma. Colony white to very pink coloured velvety. Conidiospores short and branched, usually form erumpent cream coloured sporodochia. Micro conidia hyaline to brownish white, oval to ellipsoid, produced abundantly in culture measuring $4.8-14.4 \times 2.2-4.8$ micrometre in size. Macro conidia were elongated, fusiform, falcate to cylindrical, 3 to 5 septate and measured $21.0-41 \times 2.4-5.6$ micro meter in size (Plate-1) (Saharan et al., 2005).

\section{Pathogenicity test of Fusarium oxysporum f.sp. lini}

Pathogenicity test of the isolate obtained from affected linseed roots was done on the same host to establish the pathogenic nature of the fungus. The experiment was carried out in pots filled with approximately $5 \mathrm{~kg}$ sterilized soil. The inoculum was prepared by growing the pure culture of fungus on sand cum meal (9:1) medium in $250 \mathrm{ml}$ conical flasks. Each flask was then inoculated with pure culture of $F$. oxysporum f. sp. lini and incubated at room temperature for 15 days. Inoculation of soil was done 7 days before sowing by thoroughly mixing soil with fungus culture grown on sand cum meal medium in separate pots. In control pots, sterilized sand, cum meal medium without fungal inoculum was mixed and surface sterilized seeds of Chambal were sown in pots. The pots kept in green house were observed critically for seedling emergence and wilt incidence symptoms and confirming with Koch's postulates (Plate-2).

\section{Varietal management}

The experiment was conducted under wilt sick field condition at Crop Research Farm, C. S. Azad University and Technology, Kanpur (U.P.) During 2016-2017, eleven cultivars namely, Jeevan, Sweta, Parvati, Surbhi, NDL2004-05, Kiran, RLC-92, Indira Alsi, Dipika, Shekhar including susceptible cultivar Chambal were sown in the month of October, 2016. In Randomized Block Design (RBD) with three replications, plot size of $3 \times 1.5$ meter with plant to plant spacing of $25 \mathrm{~cm} \mathrm{x}$ $10 \mathrm{~cm}$. Recommended agronomic practices (Fertilizers $80 \mathrm{~kg} \mathrm{~N}$ and $40 \mathrm{~kg} \mathrm{P} / \mathrm{ha}$ irrigation three) were adopted to rain the good crop. Crop was watched for the appearance of disease. Maximum disease severity in each varieties and seed yield per plot $(\mathrm{kg})$ were recorded separately.

\section{Evaluation of sowing dates}

The experiment was conducted in Crop Research Farm, C. S. Azad University of Agriculture and Technology, Kanpur (U.P.) Different dates of sowing, starting from 10 October to 09 December, 2017 after 10 days 
intervals under wilt sick field. In RBD having three replications, plot size was $3 \mathrm{~m} \times 1.5 \mathrm{~m}$ and variety used of Chambal. Initial plant population was noted. Each Date of sowing reported wilt incidence was observed regularly and final date was recorded as a maturity of crops in each treatment reported. The per cent disease incidence was calculated as-

Per cent wilt incidence
$\frac{\text { No. of wilted plants }}{\text { Total no. of plants }} \times 100$

\section{Results and Discussion}

\section{Evaluation of different varieties against wilt of linseed}

The studies were carried out to find the suitable variety against Fusarium wilt of linseed. Eleven cultivars namely, Jeevan, Sweta, Parvati, Surbhi, NDL-2004-05, Kiran, RLC-92, Indira Alsi, Dipika, Shekhar including susceptible cultivar Chambal were sown in the month of October, 2016, (Plate-3) under well-developed sick field conditions. The data presented in the Table 1 and Figure 1 showed that the initial plant population was noted after germination in each cultivar. Average initial plant population per plot in different cultivars was noted in between 490.50 to 537.67 plants/plots, maximum being in Shekhar and minimum in Jeevan. Susceptible check Chambal has average initial plant population of $490.67 /$ plot after germination. Wilting of the plants started in different cultivars after 15 to 20 days of sowing, which gradually increased up to maturity of crops. The minimum percentage of wilting was recorded in cultivar RLC-92 (5.47 per cent) followed by Jeevan (07.61 per cent) and Indira Alsi (07.85 Per cent), respectively but all were at par statistically. Maximum per cent wilting was recorded in susceptible cultivar Chambal (70.87 Per cent) followed by Sweta (61.64 Per cent), Shekhar (61.50 Per cent) and Parvati (46.01 Per cent). The latter were also at par among them. Maximum seed yield of $996.29 \mathrm{~kg} / \mathrm{ha}$ was recorded in cultivar RLC-92 followed by Dipika $(914.07 \mathrm{~kg} / \mathrm{ha})$ and NDL-2004-5 (909.62 kg/ha), respectively, which was significantly higher over others. Yields of Indira Alsi and Jeevan were also significantly higher over other test cultivars. Minimum yield was recorded in Shekhar $(194.07 \mathrm{~kg} / \mathrm{ha})$ followed by Chambal $(252.59 \mathrm{~kg} / \mathrm{ha}), \quad$ Sweta $(282.22 \mathrm{~kg} / \mathrm{ha})$ and Parvati (328.14kg/ha) respectively. Statistically all these were at par among them. Singh and Singh (2011) also evaluated commercially grown cultivars namely Jawahar-23, Jeevan, Kiran, Padmini, R-552, Surbhi, Type-397 and Chambal against wilt disease under sick field condition for evaluation of their resistance and yield concurrent with present findings. They have also reported Jeevan and Surbhi as resistant and moderately resistant respectively with higher yield. However, in present finding NDL-2004-05 gave maximum yield $(955.55 \mathrm{~kg} / \mathrm{ha})$ and showed resistant reaction. The cultivar Jeevan and Surbhi were reported resistant by Kishor et al., (2011) from Faizabad also. These cultivars may be sown in wilt prone areas of different genotypes/cultivars by different workers time to time (Goel and Swarup, 1964; Kulkarni et al., 1966; Pant et al., 2001 and Singh et al., 2012).

Evaluation of suitable sowing date to manage the wilt under wilt-sick field condition

Management of disease through manipulation of date of sowing is a cheapest and best method of disease control. To find out the suitable date for the management of wilt in linseed, linseed cultivar Chambal was sown in 7 different dates starting from 10 October, 2017 to 9 December, 2017 of 10 days intervals (Plate 4). 
Table.1 Evaluation of different varieties against wilt of linseed

\begin{tabular}{|c|c|c|c|c|c|c|}
\hline Varieties & $\begin{array}{c}\text { Initial } \\
\text { plant } \\
\text { population }\end{array}$ & $\begin{array}{l}\text { No. of } \\
\text { wilted } \\
\text { plant }\end{array}$ & $\begin{array}{l}\text { Final plant } \\
\text { population }\end{array}$ & $\begin{array}{c}\% \text { plant } \\
\text { wilted }\end{array}$ & $\begin{array}{c}\text { Seed yield } \\
\text { per plot } \\
\text { (Kg) }\end{array}$ & $\begin{array}{c}\text { Seed yield } \\
\text { (Kg/ha.) }\end{array}$ \\
\hline Jeevan & 490.50 & 37.00 & 453.67 & 7.61 & 0.388 & 861.48 \\
\hline Chambal & 490.67 & 374.00 & 153.67 & 70.87 & 0.114 & 252.59 \\
\hline Sweta & 515.33 & 314.3 & 197.33 & 61.64 & 0.126 & 282.22 \\
\hline Parvati & 513.67 & 236.33 & 277.33 & 46.01 & 0.147 & 328.14 \\
\hline Surbhi & 495.33 & 70.67 & 424.67 & 14.26 & 0.343 & 762.21 \\
\hline Shekhar & 537.67 & 327.33 & 228.00 & 61.50 & 0.088 & 194.07 \\
\hline $\begin{array}{l}\text { NDL-2004- } \\
05\end{array}$ & 516.33 & 56.67 & 463.00 & 10.64 & 0.409 & 909.62 \\
\hline Kiran & 508.33 & 174.00 & 334.33 & 34.23 & 0.208 & 462.22 \\
\hline RLC-92 & 511.00 & 28.00 & 483.00 & 5.47 & 0.449 & 996.29 \\
\hline Indira Alsi & 509.00 & 40.00 & 469.00 & 7.85 & 0.394 & 874.81 \\
\hline Dipika & 512.00 & 47.00 & 465.00 & 9.19 & 0.412 & 914.07 \\
\hline G.M. & 512.45 & 155.03 & 359.00 & 29.93 & 0.28 & 621.61 \\
\hline SEm \pm & 3.83 & 8.95 & 10.29 & 2.68 & 0.03 & 26.11 \\
\hline CD at $5 \%$ & 11.29 & 26.40 & 30.37 & 7.89 & 0.08 & 77.03 \\
\hline
\end{tabular}


Table.2 Effect of date of sowing on disease severity and seed yield

\begin{tabular}{|l|l|l|l|l|l|l|l|}
\hline Date of & $\begin{array}{l}\text { Date of } \\
\text { sowing } \\
\text { disease } \\
\text { appearance }\end{array}$ & $\begin{array}{l}\text { Initial } \\
\text { plant } \\
\text { population }\end{array}$ & $\begin{array}{l}\text { No. of } \\
\text { wilted } \\
\text { plant }\end{array}$ & $\begin{array}{l}\text { Final plant } \\
\text { population }\end{array}$ & $\begin{array}{l}\text { \% plant } \\
\text { wilted }\end{array}$ & $\begin{array}{l}\text { Seed } \\
\text { yield/ } \\
\text { plot } \\
\text { (Kg) }\end{array}$ & $\begin{array}{l}\text { Seed } \\
\text { yield } \\
\text { (Kg/ha.) }\end{array}$ \\
\hline $\mathbf{1 0 / 1 0 / 2 0 1 7}$ & $28 / 10 / 2017$ & 510.00 & 340.00 & 170.00 & 66.66 & 0.15 & 322.22 \\
\hline $\mathbf{2 0 / 1 0 / 2 0 1 7}$ & $08 / 11 / 2017$ & 534.00 & 327.00 & 207.00 & 61.23 & 0.19 & 411.85 \\
\hline $\mathbf{3 0 / 1 0 / 2 0 1 7}$ & $19 / 11 / 2017$ & 528.00 & 265.00 & 253.00 & 50.19 & 0.19 & 414.81 \\
\hline $\mathbf{0 9 / 1 1 / 2 0 1 7}$ & $28 / 11 / 2017$ & 503.00 & 220.00 & 283.00 & 43.74 & 0.20 & 434.81 \\
\hline $\mathbf{1 9 / 1 1 / 2 0 1 7}$ & $06 / 12 / 2017$ & 480.00 & 157.00 & 324.00 & 32.64 & 0.26 & 582.95 \\
\hline $\mathbf{2 9 / 1 1 / 2 0 1 7}$ & $19 / 12 / 2017$ & 478.00 & 99.00 & 379.00 & 20.72 & 0.19 & 418.53 \\
\hline $\mathbf{0 9 / 1 2 / 2 0 1 7}$ & $29 / 12 / 2017$ & 468.00 & 67.00 & 401.00 & 14.31 & 0.11 & 239.92 \\
\hline G.M. & $\mathbf{5 0 0 . 1 4}$ & $\mathbf{5 0 0 . 1 4}$ & $\mathbf{2 1 0 . 7 1}$ & $\mathbf{2 8 8 . 1 4}$ & $\mathbf{4 1 . 3 6}$ & $\mathbf{0 . 1 8}$ & $\mathbf{4 0 3 . 5 8}$ \\
\hline SEm & $\mathbf{7 . 8 1}$ & $\mathbf{7 . 8 1}$ & $\mathbf{1 2 . 5 2}$ & $\mathbf{1 1 . 4 6}$ & $\mathbf{0 . 7 9}$ & $\mathbf{0 . 0 2}$ & $\mathbf{2 1 . 8 0}$ \\
\hline CD at 5 \% & $\mathbf{2 4 . 0 7}$ & $\mathbf{2 4 . 0 7}$ & $\mathbf{3 8 . 5 7}$ & $\mathbf{3 5 . 3 1}$ & $\mathbf{2 . 4 3}$ & $\mathbf{0 . 0 7}$ & $\mathbf{6 7 . 1 6}$ \\
\hline
\end{tabular}

Plate.1 Pure culture of Fusarium oxysporum f.sp. lini and its conidia

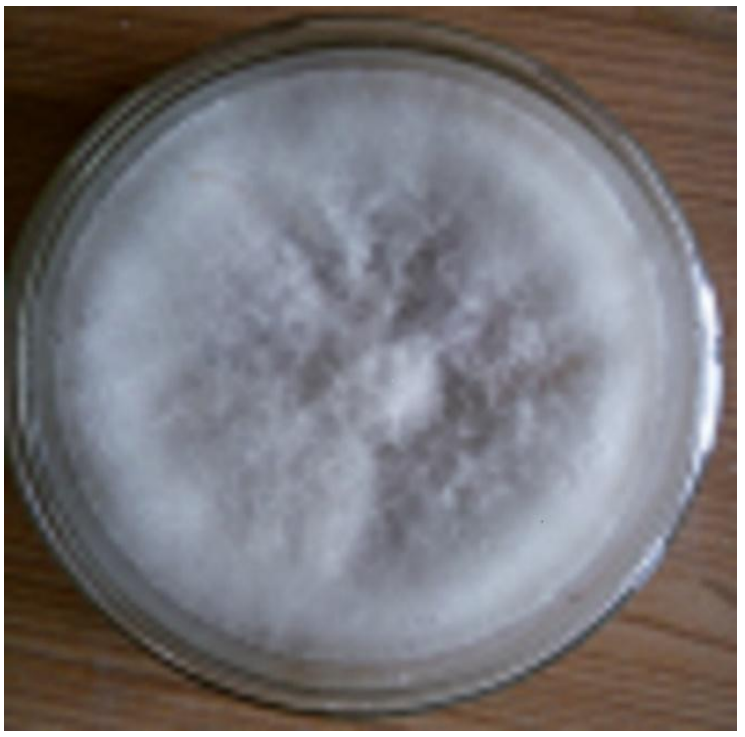

A. Pure culture of Fusarium oxysporum f.sp. lini

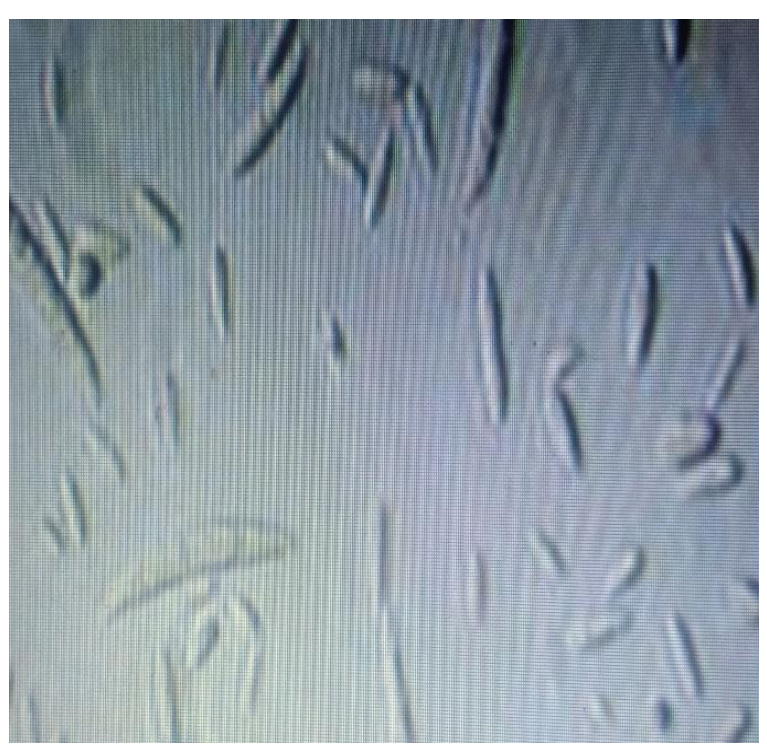

B. Micro and Macroconidia 
Plate.2 Pathogenicity test

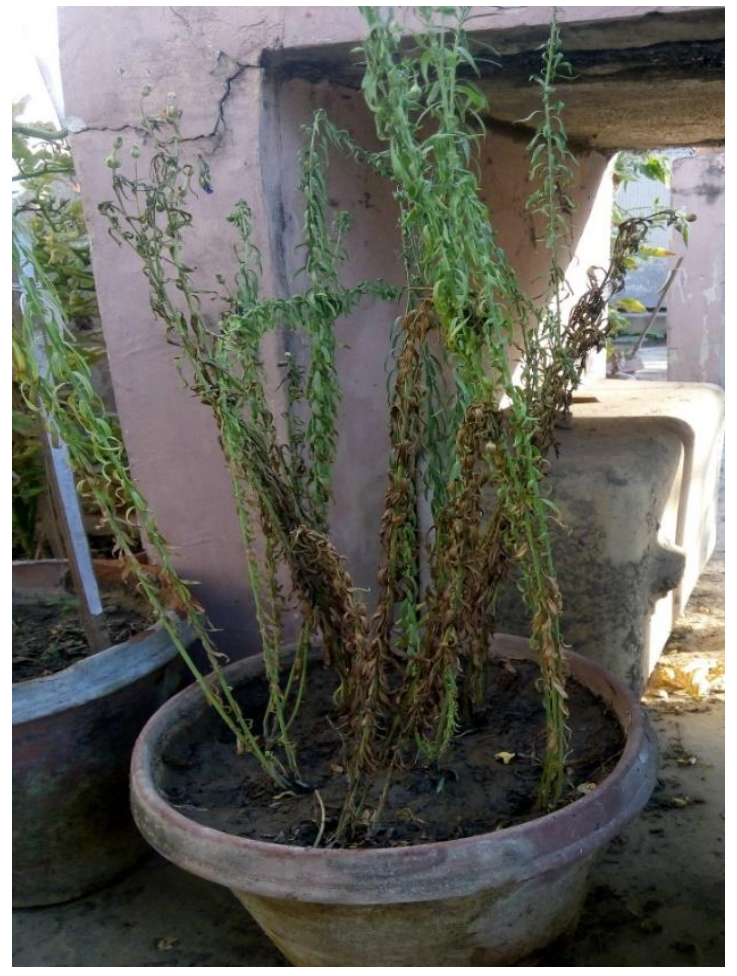

A

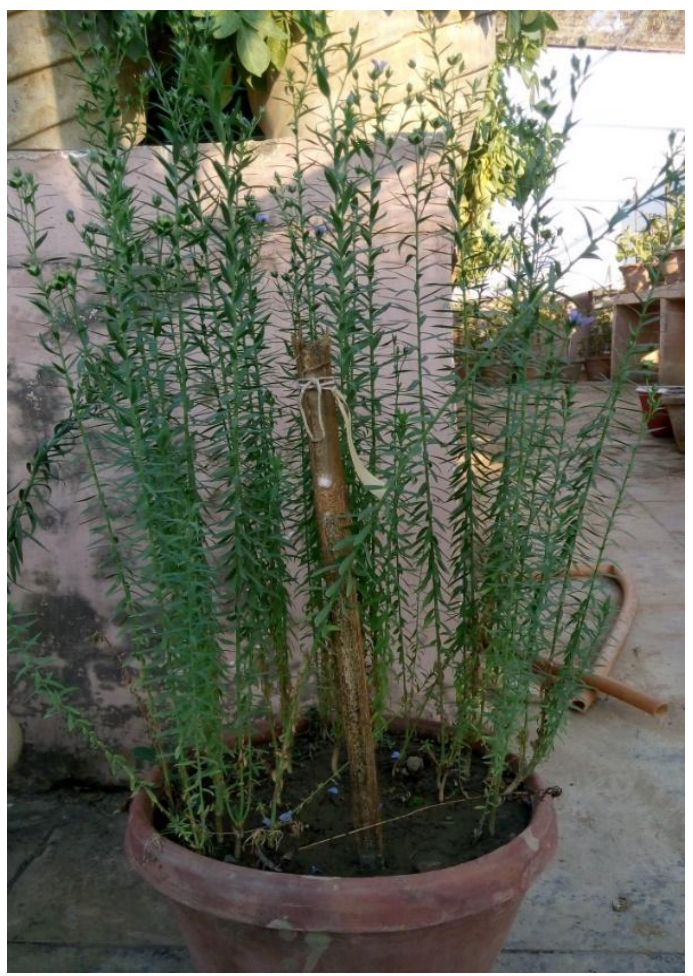

$\mathrm{B}$

A-: Inoculated plants

B-: Healthy plants
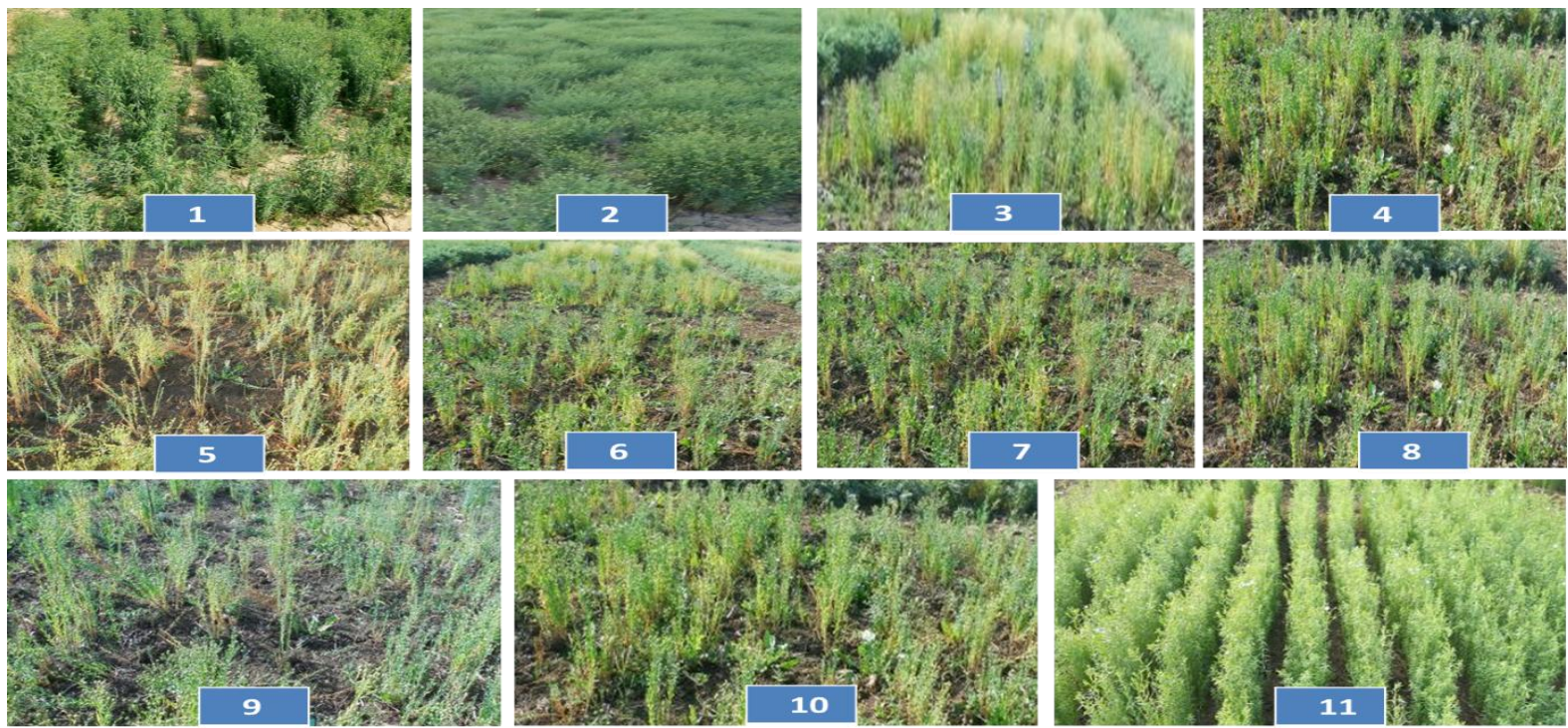

Plate-3: Plots showing susceptibility of different varieties to the pathogen

1-Jeevan, 2-Chambal， 3-Sweta,4-Parvati,5-Surbhi,6-Shekhar， 7-NDL-2004-05,8-Kiran,9RLC-92,10-Indira Alsi, 11-Dipika 
Plate.4 Field view of variety Chambal sown at different dates

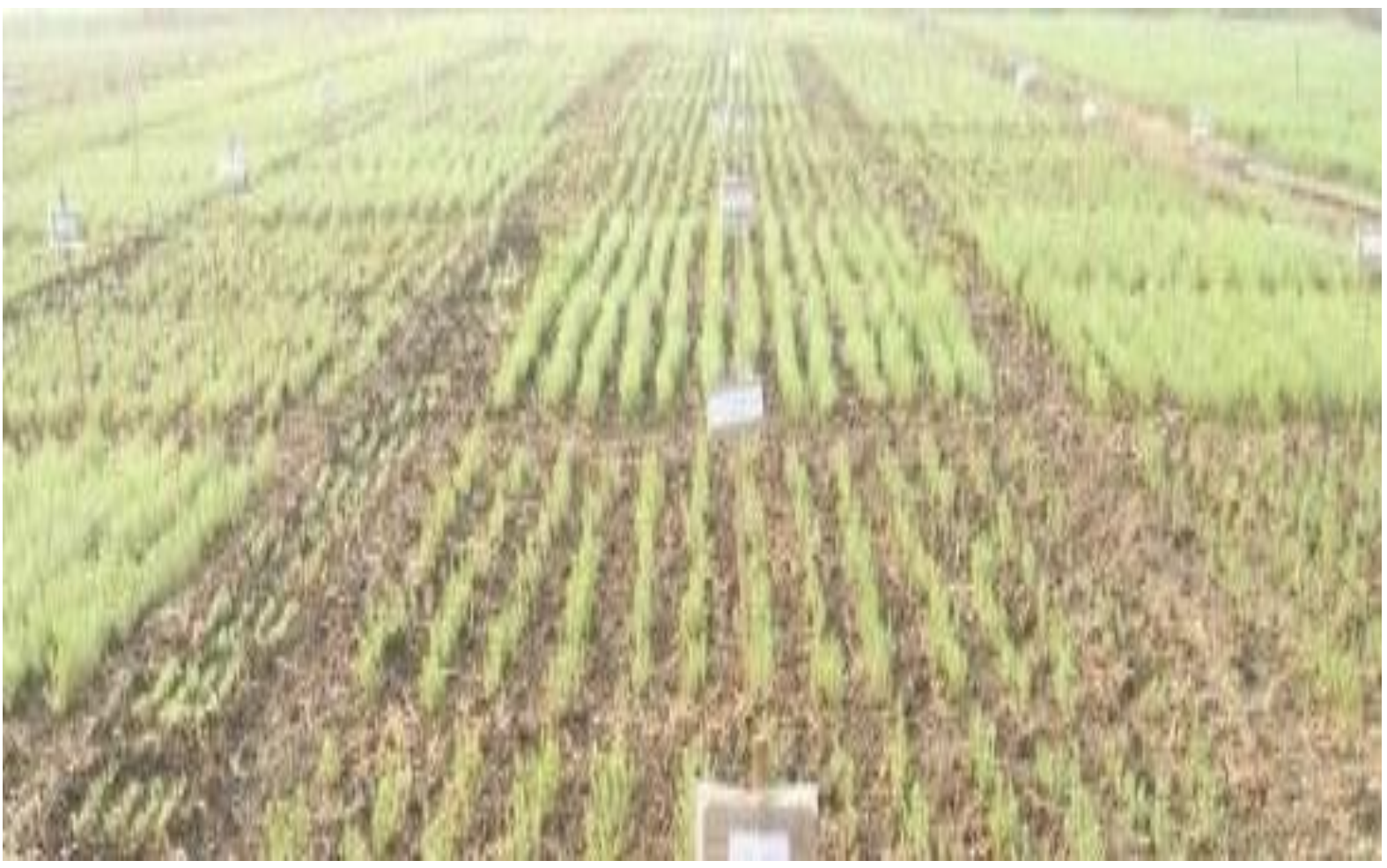

Fig.1 Evaluation of different varieties against wilt of linseed

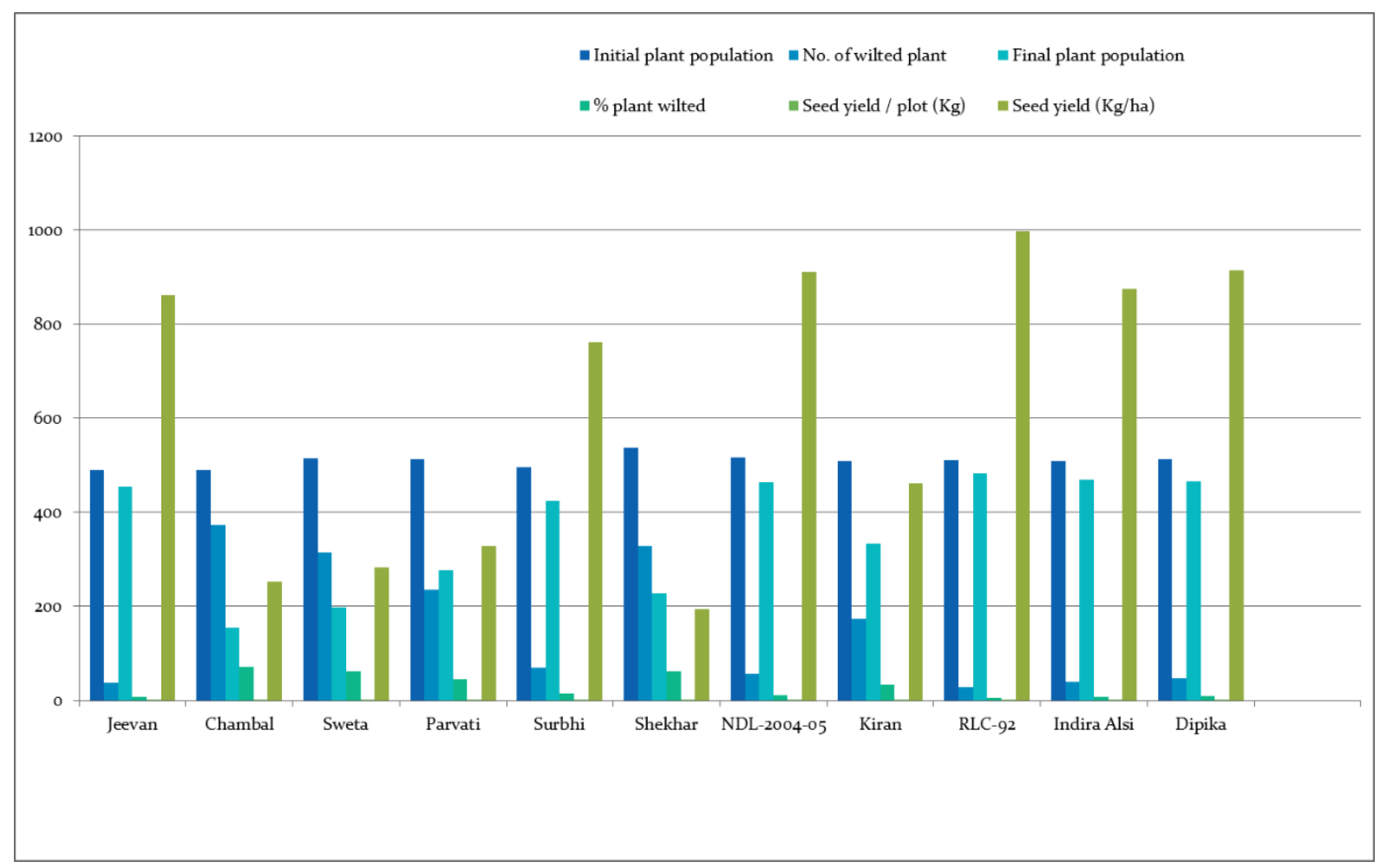


Fig.2 Effect of date of sowing on disease severity and seed yield

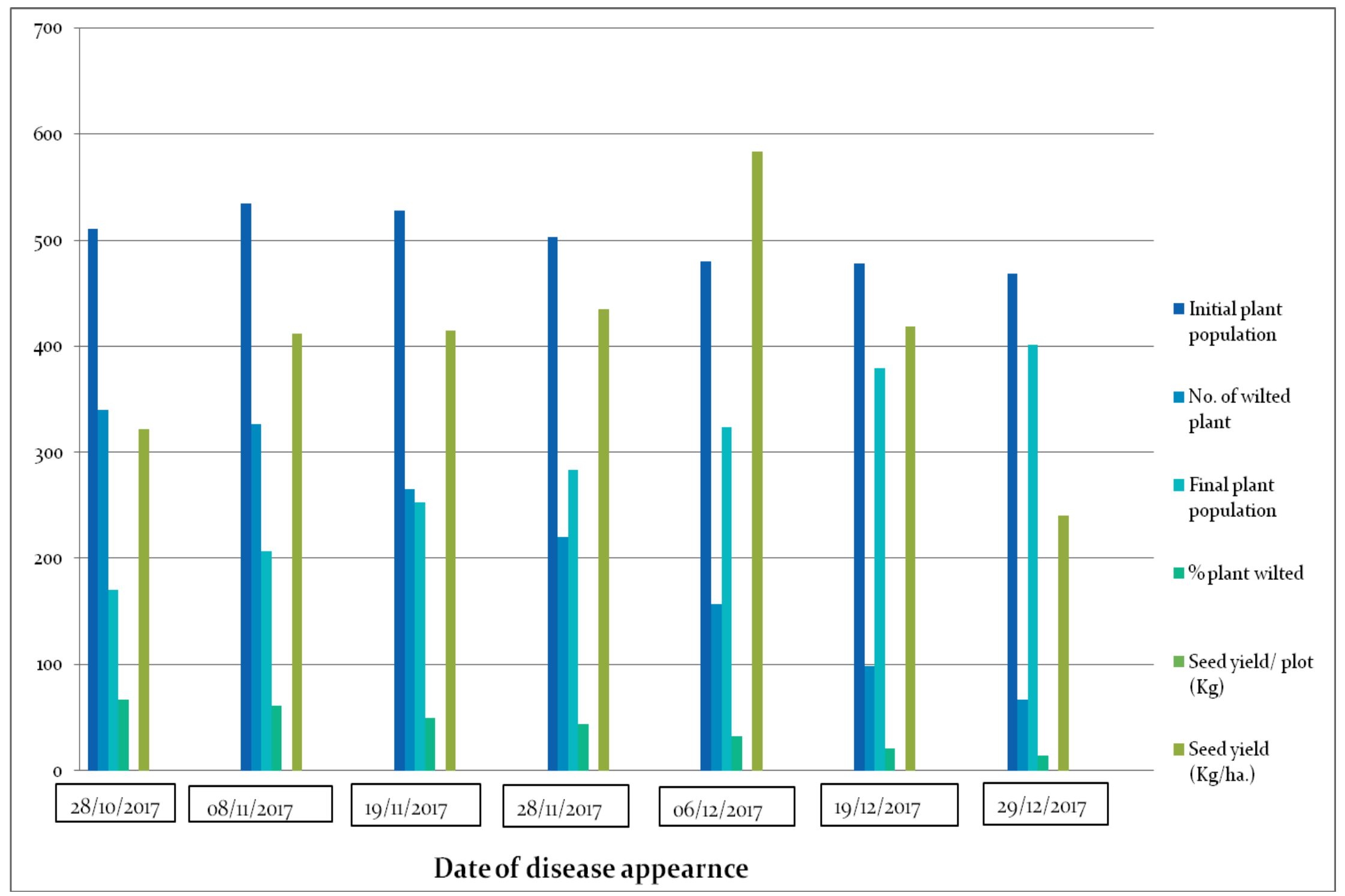


The incidence of disease and seed yield was recorded and data were presented in Table 2 and Figure 2. A perusal of the table indicated that wilting started 18-20 days after sowing in October sown crops, 17-20 days in November sown and after 19 days of sowing in December sown crops. Maximum wilting of plants (66.66 per cent) were noted in $1^{\text {st }}$ date (10-10-2017) of sowing which decreased with delayed sowing and minimum (14.31 per cent) was recorded in December sown (09-122017) crop. Significant difference in wilting percentage was noted in crops sown on different dates.

Maximum yield of $582.95 \mathrm{~kg} / \mathrm{ha}$ was noted in crop sown on 19-11-2017 followed by crop sown on $09-11-2017(434.81 \mathrm{~kg} / \mathrm{ha})$ and 30 $10-2017$ (414.81kg/ha), respectively. The yield obtained from the crop sown on 19-112017 was significantly higher over other date of sowing while the yield obtained in the crops sown on November, 09 and October, 30, 2017 was at par. These were found also at par with yield obtained in 20 October, 2017 sown crops.

Crop sown under wilt free conditions (normal condition) has been noted to yield highest under 5 November sowing (Singh and Singh, 2004). Thus, 19 November seen to be an ideal date for sowing under wilt infested conditions. However, to spread the field operations over a reasonably longer period of time, period from 09 November to 19 November seems to be reasonably good as yields obtained these two dates are higher concurrent with present findings.

Singh and Singh (2011) have also reported that sowing of linseed between 5 and 15 November in wilt sick field results in lower disease severity and higher seed yield. Maximum incidence of wilt was also reported in 20 October sown crop and minimum in 09 December sown (Kishor et al., 2008).

\section{References}

Choi, Y.W., Hyde, K.D. and Ho, W.H. (1999). Single spore isolation of fungi. Fungal Diversity 3: 29-38.

Goel, L. B. and Swarup, G. (1964). Some observations on linseed. Indian Phytopath, 17 (2): 133.

Kishor, K., Singh, J. and Pandey, M. (2008). Management of wilt disease caused by Fusarium oxysporum f. sp. lini in linseed through cultural practices. Annals of Plant Protection Science. 16 (2): 245-247.

Kishor, R., Pandey, M., Tripathi, U.K. and Singh, J. (2011). Evaluation of elite genotypes of linseed against Fusarium wilt. Indian Phytopathology. 64 (2): 203.

Kolte, S.J. and Fitt, B.D.L. (1997). Disease of linseed and Fibre Flax. p. 247. Shipra Publication, Delhi.

Kulkarni, N. B., More, B. B. and Patil, P. L. (1966). Occurrence of a new race of Fusarium oxysporum f. sp. lini (Bolley) Snyder and Hansen inciting linseed wilt. Indian Mycopath. Mycol. Appl. 38 (3): 243.

Pant, S. C., Singh, R. and Singh, B. K. (2001). Screening of linseed germplasm against wilt disease. Ann. PI. Protec. Sci., 9 (2): 334-336.

Rae, M.C. (1926). Report of the imperial mycologist. Sci. Rep. Agric. Res. Inst. Pusa. 57-69.

Saharan, G.S., Mehta, N. and Sangawan, M.S. (2005). Disease of oilseed crops. Indus Publishing Co., New Delhi.

Sattar A, Hafiz A. (1952). Researches on plant diseases of Punjab. Sci. Mongr. Pak. Assoc. Adv. Sci., 1(3): 158.

Singh, R. B. and Singh, R. N. (2004). Occurrence and management of Altemaria blight of linseed. Plant Disease Research, 19 (2):120-124. 
Singh, R. B. and Singh, R. N. (2011). Date of sowing and varieties for the management of root-rot wilt complex of linseed (Linum usitatissimum L.). Indian Journal of Agricultural Sciences, 81(3): 287-289.
Singh, R. B., Singh, H. K. and Parmar, A. (2012). Identification of resistant sources to Fusarium wilt of linseed (Linum usitatissimum L.). Plant Archives, 12 (1): 329-330.

\section{How to cite this article:}

Somesh, Narendra Singh and Sumit Kumar. 2019. Evaluation of Suitable Sowing Dates and Varieties for the Management of Linseed (Linum usitatissimum L.) wilt Under Wilt-Sick Field Conditionincited by Fusarium oxysporum f.sp. lini. (Bolley) Synder and Hansen. Int.J.Curr.Microbiol.App.Sci. 8(08): 1717-1727. doi: https://doi.org/10.20546/ijcmas.2019.808.203 